\title{
PENGARUH TIPE PEMBELAJARAN SNOWBALL THROWING TERHADAP HASIL BELAJAR SISWA
}

\author{
Mukti Ratnasari ${ }^{1}$, Marchasan Lexbin ${ }^{2}$ \\ 1,2 IKIP Siliwangi Bandung \\ 1'mukti.ratnasari2013@gmail,com, ${ }^{2}$ marchasanlexbin@yahoo.com
}

\begin{abstract}
This study aims to examine student learning outcomes using the type of snowball throwing learning towards student learning outcomes in mathematics subjects at MTs Islam Al-Maziyyah cianjur. The use of the method in this study is quasi-experimental with pretest and posttest equivalent to the control group design. Students of class VII Islamic MTs Al-Maziyyah cianjur which amounted to 3 classes were used as the population for this study while the research sample was class VII A as an experimental class that was treated with snowball throwing learning and VII C as a control class received normal learning treatment. The research instrument was in the form of student training experiments. The results showed that the influence of the relevant use of the type of snowball throwing learning was influenced on student learning outcomes from those using the usual approach.
\end{abstract}

Keywords: Learning Type Snowball Throwing, Student Learning Outcomes.

\begin{abstract}
Abstrak
Penelitian ini bertujuan untuk menelaah hasil belajar siswa dengan menggunakan tipe pembelajaran snowball throwing terhadap hasil belajar siswa pada matapelajaran matematika di MTs Islam AlMaziyyah cianjur. Penggunaan metode dalam penelitian ini yaitu kuasi eksperimen dengan pretest dan postest ekivalen dengan desain kelompok kontrol. Murid kelas VII MTs Islam Al-Maziyyah cianjur yang berjumlah 3 kelas dijadikan sebagai populasi untuk penelitian ini sementara sampel penelitiannya yaitu kelas VII A sebagai kelas eksperimen yaitu mendapat perlakuan pembelajaran snowball throwing dan VII C sebagai kelas kontrol mendapat perlakuan pembelajaran biasa. Instrumen penelitian berupa hitungan percobaan latihan siswa. Hasil penelitian menunjukan bahawa dipengaruh pengaruh yang relevan penggunaan tipe pembelajaran snowball throwing terhadap hasil belajar siswa dari yang menggunakan pendekatan biasa.
\end{abstract}

Kata Kunci: Tipe Pembelajaran Snowball Throwing, Hasil Belajar Siswa.

Ratnasari, M., Lexbin, M. (2019). Pengaruh Tipe Pembelajaran Snowball Throwing Terhadap Hasil Belajar Siswa. JPMI - Jurnal Pembelajaran Matematika Inovatif, 2 (5), 323-328.

\section{PENDAHULUAN}

Kemampuan siswa dalam Matematika mewujudkan dasar dan alat pokok yang menjadi syarat mutlak yang harus dikuasai untuk mendidik siswa berpendapat dengan jelas, logis, teratur, sistematis, bertanggung jawab, dan memiliki kepribadian yang baik serta keterampilan untuk menyelesaikan persoalan dalam kehidupan sehari-hari. Daryanto (2012) membelajarkan matematika kepada siswa, apabila guru masih menggunakan paradigma pembelajaran lama dalam arti komunikasi dalam pembelajaran matematika cenderung berlangsung satu arah umumnya dari guru ke siswa, guru lebih mendominasi pembelajaran maka pembelajaran cenderung monoton sehingga mengakibatkan peserta didik merasa jenuh dan tersiksa. Untuk itu perlu adanya motivasi dan tipe pembelajaran yang menarik, motivasi siswa dalam mempelajari Matematika sangat diperlukan, sebab tanpa adanya motivasi maka murid sulit 
menanggapi matapelajaran yang diberikan oleh guru, dan idealnya jika guru mengajar diberikan tipe pembelajaran bervariasi maka minat belajar siswa akan meningkat yang sangat berpengaruh pada hasil belajarnya.

Berdasarkan pengamatan yang peneliti lakukan kepada guru kelas VII yaitu ibu Risnawati, S. Pd menemukan bahwa cara penyampaian materi di dalam kelas masih terdapat kondisi proses pembelajaran berpusat pada guru), bentuk penyajian materi yang kurang bervariasi, serta cenderung penggunaan tipe pembelajaran yang monoton menyebabkan kebosanan bagi siswa. Sedangkan masalah yang diperoleh pada pelajaran Matematika adalah sebahagian besar kurang tertariknya murid terhadap matapelajaran Matematika yang sebagian besar Matematika berkaitan terhadap rumus-rumus serta konsep yang abstrak sehingga susah dimengerti oleh siswa. Maka tercipta suasana kelas yang tidak kondusif, sangat terlihat dengan suasana kelas ribut dan sebagian siswa juga bercerita disaat guru menerangkan pelajaran serta ketika ditanyai kebanyakan siswa yang tidak mencerna matapelajaran yang diajarkan.

Mengajarkan Matematika diperlukan tipe pengajaran yang tepat, sesuai dengan tujuan Matematika yang akan disampaikan sehingga siswa dapat belajar secara aktif dan pengajaran Matematika menjadi bermakna. Tipe pembelajaran membentuk salah satu bagian dalam kurikulum pengajaran Matematika dan termasuk faktor yang mempengaruhi proses pelajaran dan keberhasilannya. sebagian tipe pembelajaran Matematika yang dapat mempengaruhi hasil belajar adalah dengan menggunakan tipe pembelajaran Snowball Throwing. Menurut Faturrohman (2015) mengungkapkan bahwa pembelajaran Snowball Throwing dapat melatih murid untuk lebih tanggap menerima pesan dari orang lain dan menyampaikan kembali pesan tersebut kepada teman kelompoknya. Menurut fauzi M ( 2009) tiga ciri tipe pembelajaran Snowball Throwing yaitu: 1) komunikatif; 2) sistem belajar dua arah yakni guru dan sisiwa sama-sama berperan aktif; 3) menyenangkan.

Adapun lima karakteristik tipe pembelajaran Snowball Throwing adalah sebagai berikut: 1) murid bekerja dalam kelompok kooperatif untuk menguasai materi akademis; 2) Siswa diberikan pertanyaan-pertanyaan untuk mengasah pemahaman murid tentang ruang lingkup materi ; 3) Penilaian yang diberikan dalam pembelajaran disudutkan pada hasil kerja kelompok. Namun demilian, guru perlu menyadari, bahwa sebenarnya prestasi yang diharapkan adalah prestasi setiap individu siswa; 4) Siswa belajar bekerjasama, siswa juga harus belajar bagaimana membangun kepercayaan diri dan 5) Sistem penghargaan yang berorientasi kepada kelompok dari pada individu. Dari latar belakang masalah di atas, maka rumusan masalah yang akan dibahas pada penelitian ini yaitu (1) Apakah terdapat pengaruh yang relevan antara tipe pembelajaran Snowball Throwing dengan pembelajaran biasa, (2) Bagaimana hasil belajar murid dengan menggunakan tipe pembelajaran Snowball Throwing dalam pelajaran Matematika.

\section{METODE}

Proses penelitian yang digunakan pada penelitian ini adalah penelitian eksperimen semu atau quasi eksperiment. Wulandari (2018). Desain penelitian dari kuasi eksperimen yaitu pretest posttest desain kelompok kontrol, kedua dari kelompok yang telah dibentuk diberi pretes, diberikan treatment atau perlakuan dan diberikan postes. Dimana yang di dalamnya terdapat kelas eksperimen dan kelas kontrol. Kelas eksperimen memperoleh pembelajaran dengan 
pembelajaran Snowball Throwing dan kelas kontrol memperoleh pembelajaran biasa. Populasi pada penelitian ini adalah semua murid kelas VII MTs Islam Al-Maziyyah Cianjur yang terdiri dari 3 kelas. Sampel yang terpilih adalah murid kelas VII yang berjumlah dua kelas yaitu eksperimen dan kontrol. Kelas VIIA dijadilan kelas eksperimen yang diberi perlakuan snowball throwing kemudian kelas VIIC dijadikan kelas kontrol yang diberi perlakuan pendekatan konvensional. Instrumen percobaan adalah soal tes, soal tes ini berbentuk uraian dan dalam penskorannya menggunakan rubrik penskoran.

\section{HASIL DAN PEMBAHASAN}

\section{Hasil}

Hasil dari percobaan diperoleh dari pengolahan data pretes dan postes pada kelas eksperimen dan kelas kontrol. Kedua data yang diolah berasal dari hasil belajara siwa, baik yang menggunakan pembelajaran snowball throwing dan yang tidak. Pelaksanaan percobaan soal tes tersebut dilaksanakan sebelum dan sesudah mendapatkan perlakuan (treatment). Berikutnya, data pretest-posttest itu ditelaah dengan melakukan Uji normalitas, uji homogenitas dan uji beda dua rata-rata. Untuk melihat apakah terdapat pengaruh yang relevan terhadap kelas yang menggunakan pembelajaran Snowball Throwing dan pendekatan konvensional untuk lebih tegasnya disajikan dalam hasil berikut:

\section{Analisis Data Tes Hasil Belajar Siswa Kelas Eksperimen dan Kelas Kontrol}

Tabel 1. Deskripsi Data Kelas Eksperimen dan Kelas Kontrol

\begin{tabular}{llllllll}
\hline Kelas & $\mathrm{N}$ & \multicolumn{3}{c}{ Pretes } & \multicolumn{3}{c}{ postes } \\
\cline { 2 - 8 } & & Rata-rata & StDev & Pencapaian & Rata-rata & StDev & Pencapaian \\
& & & Hasil Pretes & & & Hail Postes \\
Eksperimen & 27 & 7,667 & 2,532 & $31,95 \%$ & 19,07 & 1,979 & $79,46 \%$ \\
Kontrol & 27 & 8,778 & 2,732 & $36,56 \%$ & 16,33 & 1,732 & $68,04 \%$ \\
& & & & Skor max & $=24$ & & \\
\hline
\end{tabular}

Pada tabel di atas, diperoleh terdapat perbedaan yang signifikan antara kelas eksperimen dan kontrol pada taraf $\alpha=0,05$. Jika dilihat dari rata-rata kelas eksperimen untuk data pretes 7,667 dan kelas kontrol 8,778 dan pencapain hasil pretes pada kelas eksperimen $31,95 \%$ dan pada kelas kontrol 36,56\% pada skor maksimum 24. Dari persentasi pencapain awal hasil belajar murid pada kelas eksperimen dan pada kelas kontrol dapat disimpulkan hasil belajar siswa kedua kelas masih tergolong rendah. Namun dari rata-rata kelas eksperimen untuk data postes 19,07 dan kelas kontrol 16,33 dan pencapain hasil postes kelas eksperimen 79,46\% dan kelas kontrol $68,04 \%$ dengan skor maksimum 24 . Karena adanya beda perlakuan maka hasil akhirnyapun berbeda. Terlihat dari hasil persentase pencapaian akhir kelas eksperimen lebih baik dari kelas kontrol.

\section{Pembahasan}

Pembahasan Implementasi Pembelajaran dengan Mengggunakan pembelajaran Snowball Throwing yaitu sebagai berikut:

a. Penggunaan belajar sistim kelompok dan permainan lepar bola.Guru membentuk kelompok kemudian memanggil ketua dan memberikan Lembar Kerja Siswa supaya siswa dapat menuliskan dan menyebutkan benda-benda apa saja yang bentuk permukaannya sama dengan bangun datar segiempat dan segitiga. 
b. Menggunakan tipe yaitu menjawab soal anatar kelompok Jika ada siswa yang kurang memahami persoalan yang dipelajari maka guru memberikan penjelasan secara bertahap dimulai dari pemberian contoh tipe atau bentuknya, kemudian memberikan perintah mengidentifikasi bangun datar yang disajikandan mengisi pertanyaan-pertanyaan yang mengarah ke permasalahan tersebut memlalui pemberian arahan dan petunjuk pada bagian tertentu yang siswa pahami.

c. Interaktivitas yaitu kegiatan membandingkan atau menyimpulkan jawaban Pada LKS yang diberikan kepada siswa, disajikan petunjuk berupa kalimat yang berguna untuk mengarahkan supaya mampu mendiskusikan penyelesaian dari permasalahan menyalurkan argumen atau gagasan-gagasannya dengan cara menarik kesimpulan sesuai dengan pemahaman sendiri secara berkelompok.

Dalam hal ini, murid yang mengikuti pembelajaran dengan pembelajaran lempar bola dapat lebih mudah menahami materi dan menarik dalam kegiatan pembelkajaran sehingga berpengaruh pada hasil belajar siswa. Hal ini sejalan dengn teori Mentari (2018) bahwa pembelajaran Snowball Throwing lebih baik daripada menggunakan pembelajaran konvensional.

\section{KESIMPULAN}

Dari hasil analisis data dan pembahasan, disimpulkan bahwa pada matapelajaran matematika dengan menggunakan pembelajaran biasa dan pembelajaran tipe snowball throwing sebagai berikut: diperoleh dari hasil belajar siswa yang menggunakan pembelajaran tipe snowball throwing lebih baik daripada yang menggunakan pembelajaran biasa, dengan kategori tinggi untuk kelas eksperimen dan rendah untuk kelas kontrol pada hasil tes akhir yakni setelah mendapat perlakuan belajar. Dengan demikian dapat diambil kesimpulan bahwa pembelajaran tipe snowball throwing terdapat pengaruh terhadap hasil belajar siswa, karena mengandung beberapa strategi yang mampu merangsang antusias siswa dalam belajar serta membangun pengetahuannya sendiri melalui kontruksi konsep-konsep matematik yang saling berhubungan yang pada akhirnya siswa akan tampak lebih aktif dan lebih percaya diri.

\section{UCAPAN TERIMA KASIH}

Saya persembahkan kepada semua bagian yang terkait demi kelangsungan penelitian sampai tersusunnya laporan hasil penelitian ini. Termasuk didalamnya pimpinan IKIP Siliwangi Bandung, dosen pembimbing dan pihak MTs Islam Al-Maziyyah cianjur yang dijadikan tempat berlangsungnya penelitian.

\section{DAFTAR PUSTAKA}

Daryanto. Raharjo,M. (2012). Tipe Pembelajaran Inivatif. Yogyakarta. Gaya Media.

Fauzi M, H. (2009). Sejuta Jurus Mengajar dan Mengasyikan. Semarang. tersedia: PT. Sindau Press.

Fathurohman. M.(2015). Tipe-tipe Pembelajaran Inovatif :Aternatif Pembelajaran yang Menyenangkan.Jogjakarta. Ar-Ruzz Media. 
Mentari,P. (2018). Pengaruh Pembelajaran Snowball Throwing terhadap Hasil Belajar Siswa Matapelajaran Matematika Kelas V. Skripsi Universitas Islam Negri. Sumatra Utara.

Wulandari, A. (2018). Hubungan Antara Selp Compidence dengan Kemampuan Pemecahan Masalah Matematis Siswa SMA. Bandung. Jurnal IKIP Siliwangi [online]. Vol 1. No 4. Tersedia: https://jurnal,ikipsiliwangi.ac.id/index.php/jpmi. 
328 Ratnasari,\& Lexbin, Pengaruh Tipe Pembelajaran Snowball Throwing Terhadap Hasil... 